\title{
IMPLIKASI WORK ENGAGEMENT, FUN AT WORK, DAN JOB SATISFACTION TERHADAP ORGANIZATIONAL CITIZENSHIP BEHAVIOR PADA KARYAWAN ATRIA HOTEL GADING SERPONG
}

\author{
Respati Wulandari, Christy Ayu Sarah Panjaitan \\ Universitas Bina Nusantara \\ Jalan KH. Syahdan No. 9 Kemanggisan, Jakarta \\ Respati.wulandari@binus.edu
}

\begin{abstract}
Abstrak
Atria Hotel Gading Serpong berdiri sejak tahun 2010 di bawah naungan Parador Hotels \& Resorts. Atria Hotel Gading Serpong merupakan hotel bintang empat berstandar internasional yang berkomitmen dengan standar internasional untuk melayani kebutuhan pasar lokal di bidang konferensi dan perjalanan dinas. Tujuan penelitian ini adalah untuk mengetahui pengaruh fun at work, work engagement, dan job satisfaction terhadap OCB pada karyawan Atria Hotel Gading Serpong. Metode penelitian yang digunakan adalah metode penelitian kuantitatif dengan metode pengumpulan data menggunakan kuesioner. Teknik pengambilan sampel dilakukan dengan teknik probability sampling dengan metode proportionate stratified sampling dan menggunakan rumus slovin. Data-data yang diperoleh kemudian diolah menggunakan software IBM SPSS Statistic versi 25 . Hasil yang dicapai dalam penelitian ini menunjukkan bahwa work engagement, dan job satisfaction memiliki pengaruh positif terhadap OCB, sedangkan fun at work tidak memiliki pengaruh terhadap OCB pada karyawan Atria Hotel Gading Serpong.
\end{abstract}

Kata kunci : work engagement, fun at work, job satisfaction, OCB

\begin{abstract}
Atria Hotel Gading Serpong was built in 2010, managed by Parador Hotels \& Resort. Atria Hotel Gading Serpong is a 4-star hotel of international standard that was committed to serve the needs of the local market for conferencing, business trips and vacations. The aim of this study is to analyze the influence of the fun at work, work engagement, and job satisfaction toward organizational citizenship behavior (OCB) at Atria Hotel Gading Serpong. This study using qualitative research method and the analyzed data comes from distributed questionnaires to employees. Samples taken using probability Sampling technique with proportionate stratified sampling method using Slovin formula. All analysis was performed with IBM SPSS Statistics version 25.

The result of this study indicated that work engagement and job satisfaction fun had positif effect on OCB, but fun at work had no effect on OCB at Atria Hotel Gading Serpong.

Keywords: fun at work, work engagement, job satisfaction, OCB
\end{abstract}

\section{Pendahuluan}

Perkembangan bisnis perhotelan di Indonesia dapat dikatakan mengalami perkembangan yang cukup signifikan dari tahun ke tahun. Dihimpun dari Hotelier Indonesia Magazine (hotelier-indonesia.com, 2018), permintaan hotel di Indonesia di tahun 2017 meningkat 6,2\%, yang merupakan tingkat pertumbuhan tertinggi di Indonesia sejak tahun 2011. Para pengembang nasional maupun asing terus membidik lokasi-lokasi baru untuk membangun gedung-gedung hotel sehingga menempatkan Indonesia dalam lima besar pertumbuhan tertinggi di Asia (Nurcaya, 2017).

Tidak hanya di kota besar seperti Jakarta dan Bali, Kabupaten Tangerang pun tengah berupaya menciptakan iklim investasi yang layak bagi investor di industri perhotelan. Kabupaten Tangerang sebagai jantung penghubung provinsi Banten ke ibu kota, merupakan kabupaten yang didominasi oleh industri pengolahan, perdagangan, hotel dan restoran. Peningkatan jumlah hotel baru di 
Kabupaten Tangerang membuat para pelanggan hotel semakin menuntut dalam hal harga dan kualitas layanan, dikarenakan mereka dihadapkan pada banyak pilihan hotel. Setiap hotel saling bersaing memberikan pelayanan terbaik, sehingga peran masingmasing karyawan hotel menjadi semakin penting dan diandalkan dalam pengembangan bisnis perhotelan.

Salah satu hotel berbintang di Kabupaten Tangerang dengan fasilitas baik dan kualitas pelayanan memuaskan menurut sebagian besar tamu adalah Atria Hotel Gading Serpong (Irawan, 2016). Hotel yang sebelumnya bernama Aston Paramount Serpong ini berlokasi di samping Summarecon Mal Serpong (SMS). Lokasi Atria Hotel Gading Serpong cukup strategis, dan merupakan akomodasi yang dekat dengan Bandara Soekarno Hatta International Airport, yang hanya berjarak sekitar $14 \mathrm{~km}$. Peningkatan jumlah hotel baru di Kabupaten Tangerang menjadikan Atria Hotel Gading Serpong juga perlu mengembangkan keunggulan kompetitif hotelnya.

Terdapat banyak aspek yang dapat memengaruhi perilaku karyawan pada pengembangan keunggulan kompetitif dalam industri perhotelan, namun perilaku OCB (Organizational Citizenship Behavior) merupakan aspek utama dalam meningkatkan kualitas layanan, keunggulan kompetitif, dan financial performance di hotel (Ruizalba et al., 2014). OCB terpancar melalui dukungan karyawan yang produktif dan berkomitmen tinggi untuk mencapai tujuan secara efektif, sikap tanggung jawab dan kepedulian kepada organisasi, peran aktif karyawan dalam menyampaikan ide dalam mencapai visi dan misi organisasi, serta kepedulian pada rekan kerja dan sikap toleran dalam menciptakan suasana kerja yang kondusif.

Beberapa literatur perhotelan menyebutkan bahwa tren yang berkembang saat ini menunjukkan bahwa perilaku OCB yang dimiliki karyawan memegang peran utama dalam mengembangkan keunggulan kompetitif, sehingga hotel yang berfokus dalam meningkatkan perilaku OCB karyawannya akan lebih siap dalam menghadapi persaingan dari kompetitornya (Mark dan Zaiton, 2015; Arasli dan Baradarani, 2014; Hemaloshinee, 2017).
Penelitian terkini juga menjelaskan berbagai manfaat dan kontribusi OCB dalam industri.

Berbagai cara dilakukan oleh perusahaan untuk memunculkan perilaku seperti yang diharapkan, salah satunya dengan menciptakan lingkungan kerja yang nyaman bagi karyawan. Salah satu jenis iklim organisasi yang populer saat ini dalam menciptakan lingkungan kerja yang nyaman dan fun bagi karyawan adalah fun at work. Fun at work dapat digambarkan sebagai keterlibatan seorang individu baik secara sosial, interpersonal atau dalam pengerjaan tugas dengan fun dan penuh humor yang memberikan individu tersebut suasana yang menghibur, nyaman dan menyenangkan (Fluegge-Woolf, 2008 dalam Tews, 2015). Fun at work dapat tercipta dengan lingkungan kerja yang didesain khusus untuk membuat karyawan fun dalam bekerja, interaksi antara karyawan dengan humor, maupun dengan kegiatan-kegiatan yang mampu membuat karyawan merasa fun.

Ford et al. (2003) dalam Fluegge-Woolf (2014) menjelaskan bahwa fun at work merupakan hal penting yang harus diterapkan dalam perusahaan, karena ketika karyawan merasakan fun dalam pekerjaannya maka semangat dan produktivitasnya akan meningkat. Penelitian sebelumnya (Karl and Peluchette, 2006a; Aldag and Sherony, 2001; dalam Chan dan Mak, 2016) menunjukkan bahwa fun at work memiliki pengaruh yang positif terhadap perilaku $O C B$. Oleh karena itu, fun at work diduga penting untuk meningkatkan perilaku OCB pada karyawan di Atria Hotel Gading Serpong.

Tercapainya perilaku OCB yang baik dalam sebuah perusahaan didukung pula oleh aspek engagement yang terdapat pada karyawan (Mathumbu dan Dodd, 2013). Olivier dan Rothmann (2007) dalam Geldenhuys et al. (2014) mendefinisikan work engagement sebagai upaya pemanfaatan pekerja dalam organisasi untuk menunjukkan peran karyawan dalam bekerja dan mengekspresikan performansi mereka secara fisik, kognitif, dan emosi. Dicke et al. (2007) dalam Siswono (2016) menemukan bahwa hubungan yang kuat antara OCB dan work engagement dapat dilihat pada sikap individu yang inisiatif yaitu sikap kerja yang lebih ekstra. Work 
engagement juga dijadikan sebagai pendekatan strategi untuk pergerakan perubahan organisasi dan peningkatan kualitas organisasi (Prabhakar, 2011 dalam Yulianti dan Puteri, 2016).

Menurut marketeers.com (2016), isu seputar SDM dalam industri perhotelan berkaitan erat dengan bagaimana karyawan memberikan kepuasan kepada tamu. Hal ini sangat berhubungan langsung dengan harga, return guest ratio, reputasi merek, dan berujung pada kinerja keuangan. Namun terlepas dari itu, para pelaku hotel juga menyoroti masalah job satisfaction (kepuasan kerja karyawan). Pelaku hotel beranggapan, apabila seorang karyawan merasa senang dan puas dengan pekerjaannya, mereka akan memberikan pelayanan yang baik kepada tamu, dan kemudian kepuasan tamu pun akan turut meningkat. Gyekye dan Haybatollahi (2015) menyatakan bahwa job satisfaction merupakan prediktor yang signifikan terhadap OCB.

Dalam penelitian ini, penulis ingin membuktikan adanya pengaruh antara work engagement, fun at work, dan job satisfaction terhadap perilaku OCB karyawan dalam konteks perhotelan.

\section{Metode Penelitian}

Penelitian ini menggunakan pendekatan kuantitatif untuk menganalisa data yang didapatkan dengan menggunakan kuesioner. Menurut Sugiyono (2010:8), metode penelitian kuantitatif digunakan pada populasi atau sampel tertentu, pengumpulan data menggunakan instrumen penelitian, dan analisis data yang berupa statistik. Tujuan dari penelitian kuantitatif adalah untuk menguji hipotesis yang telah ditetapkan dan memprediksi hubungan variabel dependen dengan variabel independen. Oleh karena itu, dalam penelitian ini, peneliti ingin meneliti hubungan antara variabel independen yaitu fun at work (X1), work engagement (X2), job satisfaction (X3) dengan OCB (Y) sebagai variabel dependen.

Populasi dari penelitian ini adalah seluruh karyawan di Atria Hotel Gading Serpong yang berjumlah 150 orang. Unit analisis yang mencakup sampling unit dan element dalam penelitian ini adalah pria dan

wanita yang berstatus sebagai karyawan di Atria Hotel Gading Serpong, dan telah bekerja selama minimal 6 bulan di Atria Hotel Gading Serpong.

Penelitian ini menggunakan probability sampling techniques, dimana setiap anggota populasi memiliki peluang yang sama untuk dipilih sebagai sampel (Malhotra, 2012:371). Teknik pengambilan sampel yang dipakai oleh peneliti adalah proportionate stratified sampling. Proportionate stratified sampling merupakan teknik yang hampir sama dengan simple random sampling namun penentuan sampelnya memperhatikan strata (tingkatan) yang ada dalam populasi.

Populasi dalam penelitian ini terbagi menjadi 2 bagian yaitu operational staff (109 orang) dan back office staff (41 orang). Dengan menggunakan rumus Slovin dan tingkat kesalahan 5\%, maka didapatkan jumlah sampel sebesar 109 orang.

Tabel 1

Indikator Variabel Penelitian

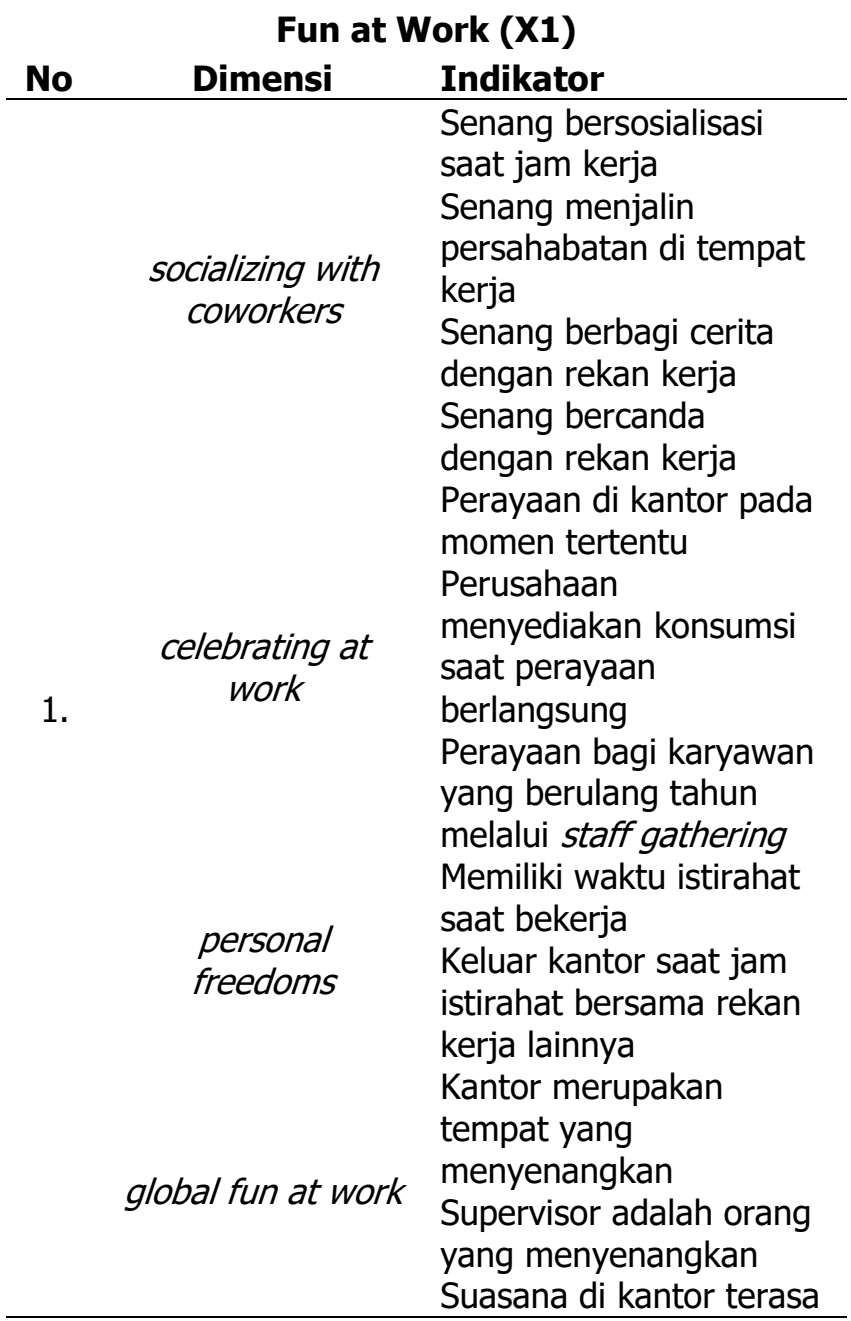




\begin{tabular}{|c|c|c|}
\hline \multirow{2}{*}{\multicolumn{3}{|c|}{$\begin{array}{r}\text { menyenangkan } \\
\text { Work Engagement (X2) }\end{array}$}} \\
\hline & & \\
\hline 2. & absorption & $\begin{array}{l}\text { Merasa penuh energi } \\
\text { Memiliki keinginan untuk } \\
\text { berusaha dalam bekerja } \\
\text { Tetap tekun meskipun } \\
\text { menghadapi kesulitan } \\
\text { dalam pekerjaan } \\
\text { Memiliki keterlibatan } \\
\text { yang kuat pada } \\
\text { pekerjaan } \\
\text { Merasa tertantang } \\
\text { Merasa antusias } \\
\text { Merasa waktu cepat } \\
\text { berlalu saat sedang } \\
\text { bekerja } \\
\text { Tenggelam dalam } \\
\text { pekerjaan }\end{array}$ \\
\hline \multicolumn{3}{|c|}{ Job Satisfaction (X3) } \\
\hline 3. & $\begin{array}{l}\text { Intrinsic- } \\
\text { satisfaction }\end{array}$ & $\begin{array}{l}\text { Ability utilization } \\
\text { Achievement } \\
\text { Advancement } \\
\text { Creativity } \\
\text { Compensation } \\
\text { Recognition } \\
\text { Working condition } \\
\text { Company policies and } \\
\text { practices } \\
\text { (Y) }\end{array}$ \\
\hline 4. & OCBO & $\begin{array}{l}\text { Membantu karyawan lain } \\
\text { tanpa ada paksaan } \\
\text { Meringankan problem } \\
\text { pekerjaan orang lain } \\
\text { Memberi semangat } \\
\text { kepada orang lain } \\
\text { Peran yang melebihi } \\
\text { standar minimum } \\
\text { Partisipasi sukarela }\end{array}$ \\
\hline
\end{tabular}

\begin{tabular}{|c|c|c|c|}
\hline & & Diploma & 31 \\
\hline & & Sarjana & 20 \\
\hline & & $\begin{array}{l}6 \text { bulan-1 } \\
\text { tahun }\end{array}$ & 47 \\
\hline 4. & Lama bekerja & $\begin{array}{l}1 \text { tahun-2 } \\
\text { tahun }\end{array}$ & 28 \\
\hline & & $\begin{array}{l}2 \text { tahun-3 } \\
\text { tahun }\end{array}$ & 14 \\
\hline & & $>3$ tahun & 20 \\
\hline & & 4 juta -5 juta & 27 \\
\hline 5 & Gaii & 5 juta -6 juta & 58 \\
\hline J. & GdJ & 6 juta -7 juta & 11 \\
\hline & & $>7,000,000$ & 13 \\
\hline & & Engineering & 10 \\
\hline & & F\&B Kitchen & 14 \\
\hline & & F\&B Service & 11 \\
\hline & & Finance \& Acct & 14 \\
\hline 6. & Departemen & Front Office & 25 \\
\hline & & Housekeeping & 19 \\
\hline & & $\mathrm{HR}$ & 4 \\
\hline & & $\begin{array}{l}\text { Sales\&Marketi } \\
\text { ng }\end{array}$ & 12 \\
\hline & & Director & 3 \\
\hline & & Manager & 10 \\
\hline 7. & Jabatan & Asst. Manager & 3 \\
\hline & & Supervisor & 17 \\
\hline & & Staff & 76 \\
\hline
\end{tabular}

Berikut merupakan hasil analisis pengaruh Fun at Work, Work Engagement, dan Job Satisfaction terhadap OCB:

Tabel 3

Hasil $R$ Square $X_{1}, X_{2}, X_{3}$ terhadap $Y$ Descriptive Statistics

Hasil dan Pembahasan

Tabel 2

Deskripsi Tabel Penelitian

\begin{tabular}{lllc}
\hline No & $\begin{array}{c}\text { Karakteristi } \\
\text { k }\end{array}$ & \multicolumn{1}{c}{ Kategori } & $\begin{array}{c}\text { Frekuen } \\
\text { si }\end{array}$ \\
1. & \multirow{2}{*}{ Jenis Kelamin } & Pria & 77 \\
& & Wanita & 32 \\
& & $<26$ tahun & 23 \\
2. & \multirow{2}{*}{ Usia } & $26-35$ tahun & 68 \\
& & $36-45$ tahun & 18 \\
3. & Pendidikan & SMA / SMK & 0 \\
\hline
\end{tabular}

\begin{tabular}{llll}
\hline & Mean & $\begin{array}{l}\text { Std. } \\
\text { Deviation }\end{array}$ & N \\
\hline OCB & 24.03 & 3.337 & 109 \\
Fun at Work & 27.39 & 8.666 & 109 \\
Work & 30.27 & 5.566 & 109 \\
$\begin{array}{l}\text { Engagement } \\
\text { Job Satisfaction }\end{array}$ & 30.91 & 4.739 & 109 \\
\hline
\end{tabular}

Model Summary

\begin{tabular}{lllll}
\hline Model & $\mathbf{R}$ & $\begin{array}{l}\mathbf{R} \\
\text { square }\end{array}$ & $\begin{array}{l}\text { Adjusted } \\
\text { R Square }\end{array}$ & $\begin{array}{l}\text { Std. Error } \\
\text { of } \\
\text { Estimate }\end{array}$ \\
\hline 1 & 0.745 & 0.555 & 0.542 & 2.259
\end{tabular}


a. Predictors: (Constant), fun_at work, work_engagement, job_satisfaction

b. Dependent Variable: $O C B$

Berdasarkan tabel 3 di atas, nilai $\mathrm{R}$ Square sebesar 0,555 (pengkuadratan dari kolom $\mathrm{R}$ atau $0,745 \times 0,745=0,555$ ) yang artinya besarnya pengaruh antara fun at work, work engagement, dan job satisfaction memengaruhi OCB (Y) sebesar $55.5 \%$ dan sisanya sebesar $0,445(100 \%-55.5 \%=$ $44.5 \%$ ) dipengaruhi oleh variabel lainnya di luar penelitian ini. $\mathrm{R}$ Square berkisar pada 0 sampai 1, semakin kecil angka $\mathrm{R}$ Square menunjukan semakin lemah hubungan antara variabel dan sebaliknya.

Kolom $\mathrm{R}$ menunjukan bahwa angka koefisien korelasi sebesar 0,745, dimana hal ini menunjukan bahwa pengaruh antara fun at work, work engagement, dan job satisfaction terhadap OCB adalah cukup kuat. Pada tabel descriptive statistics di atas bahwa nilai standar deviasi OCB sebesar 3.337 yang lebih besar dari nilai Std. Error of the Estimate yang hanya sebesar 2.259, sehingga model regresi ini baik digunakan. Dari hasil besarnya kontribusi ketiga variabel fun at work, work engagement, dan job satisfaction terhadap OCB, maka sudah seharusnya OCB mendapat perhatian lebih dari manajemen pada Atria Hotel Gading Serpong.

Berdasarkan hasil Anova pada table 4 didapat $F$ hitung sebesar 43.601 di mana $F$ hitung > F tabel atau $43.601>2,69$ ( $F$ tabel didapat dengan df1 $=$ jumlah variabel -1 atau 4-1=3 dan nilai df2 = n-k atau 109-4 = 105, sehingga nilai $F$ tabel sebesar 2,69), dan probabilitas kurang dari 0.05 . Hal tersebut menunjukkan bahwa model regresi sudah layak digunakan untuk memprediksi OCB.

Tabel 4

ANOVA ${ }^{a}$

\begin{tabular}{|cl|c|c|c|c|c|}
\hline & Model & $\begin{array}{c}\text { Sum of } \\
\text { Squares }\end{array}$ & df & $\begin{array}{c}\text { Mean } \\
\text { Square }\end{array}$ & F & Sig. \\
\hline 1 & Regression & 667.277 & 3 & 222.426 & 43.601 & $.000^{\circ}$ \\
& Residual & 535.640 & 105 & 5.101 & & \\
& & & & & \\
\hline
\end{tabular}

a. Dependent Variable : OCB

b. Predictors (constant), Job Satisfaction, Fun at Work, Work Engagement
Tabel 5

Coefficients $^{\mathrm{a}}$

\begin{tabular}{|l|c|c|c|c|c|}
\hline \multirow{2}{*}{ Model } & \multicolumn{2}{|c|}{ Unstandardize } & Std. & & \\
& \multicolumn{2}{|c|}{ d Coefficients } & Coeff. & \multirow{2}{*}{ t } & \multirow{2}{*}{ Sig } \\
\cline { 2 - 4 } & B & $\begin{array}{c}\text { Std. } \\
\text { Error }\end{array}$ & Beta & & \\
\hline (Constant) & 9.808 & 1.815 & & 5.403 & 0.000 \\
Fun at Work & -0.043 & 0.026 & -0.112 & -1.663 & 0.099 \\
Work Engagement & 0.156 & 0.060 & 0.260 & 2.600 & 0.011 \\
Job Satisfaction & 0.346 & 0.072 & 0.491 & 4.824 & 0.000 \\
\hline
\end{tabular}

a. Dependent Variable : OCB

Berdasarkan hasil coefficients pada tabel 5, diperoleh hasil:

t hitung untuk fun at work sebesar 1.663 di mana t tabel sebesar 1.6595 sehingga $t$ hitung untuk fun at work lebih kecil dari t tabel. Selain itu pada kolom Sig dapat diketahui angka Sig pada fun at work sebesar 0,099 (probabilitas diatas 0.05). Oleh karena itu dapat disimpulkan bahwa tidak terdapat pengaruh antara fun at work terhadap OCB (Ho diterima dan $\mathrm{Ha}$ ditolak).

t hitung untuk work engagement sebesar 2.600 di mana $t$ tabel sebesar 1.6595 sehingga $t$ hitung untuk work engagement lebih besar dari $\mathrm{t}$ tabel. Selain itu pada kolom Sig dapat diketahui angka Sig pada work engagement sebesar 0.011 (probabilitas dibawah 0.05). Oleh karena itu dapat disimpulkan bahwa terdapat pengaruh positif antara work engagement terhadap OCB (Ho ditolak dan $\mathrm{Ha}$ diterima).

t hitung untuk job satisfaction sebesar 4.824 di mana t tabel sebesar 1,6595 sehingga t hitung untuk job satisfaction lebih besar dari t tabel. Selain itu pada kolom Sig dapat diketahui angka Sig pada job satisfaction sebesar 0.038 (probabilitas dibawah 0.05). Oleh karena itu dapat disimpulkan bahwa terdapat pengaruh positif antara job satisfaction terhadap OCB (Ho ditolak dan $\mathrm{Ha}$ diterima). 


\section{Pengujian Hipotesis}

\section{H1: Pengaruh Fun at Work terhadap OCB}

Dari semua komponen pembentuk OCB dalam penelitian ini, ditemukan bahwa fun at work tidak memberi pengaruh terhadap OCB. Penemuan ini berbeda dengan penelitian Fluegge-Woolf (2014) yang menyatakan bahwa fun at work memiliki pengaruh yang positif dan signifikan terhadap OCB. Penelitian terdahulu terkait dengan fun at work menunjukkan bahwa penelitian mengenai konsep dari fun di lingkungan kerja penting untuk dilakukan demi menciptakan dampak positif baik bagi karyawan dan organisasi/ perusahaan.

\section{H2: Pengaruh Work Engagement terhadap OCB}

Work Engagement terbukti memiliki hubungan yang positif terhadap OCB, yaitu sebanyak $15.6 \%$. Hal ini sejalan dengan hasil penelitian yang dilakukan oleh Mathumbu dan Dodd (2013) yang menyatakan bahwa work engagement memiliki pengaruh yang signifikan dan berkorelasi positif terhadap $O C B$. Hal ini juga sejalan dengan penelitian Ziyad (2015) yang menunjukkan bahwa keterikatan kerja berpengaruh secara signifikan terhadap $O C B$.

\section{H3: Pengaruh Job Satisfaction terhadap OCB}

Job Satisfaction terbukti memberikan pengaruh paling besar terhadap OCB dibandingkan dengan komponen pembentuk OCB, yaitu sebesar 34,6\%. Hal ini sejalan dengan penelitian Gyekye dan Haybatollahi (2015) yang menyatakan kepuasan kerja merupakan prediktor yang signifikan terhadap OCB, yang dibuktikan dengan karyawan yang lebih muda akan memiliki perilaku OCB ketika merasa kepuasan kerja sudah terpenuhi.

\section{Bahasan Penelitian \\ Pengaruh Fun at Work terhadap OCB}

Dari semua komponen pembentuk OCB dalam penelitian ini, ditemukan bahwa fun at work tidak memberi pengaruh terhadap OCB. Penemuan ini berbeda dengan penelitian Fluegge-Woolf (2014) yang menyatakan bahwa fun at work memiliki pengaruh yang positif dan signifikan terhadap OCB. Penelitian terdahulu terkait dengan fun at work menunjukkan bahwa penelitian mengenai konsep dari fun di lingkungan kerja penting untuk dilakukan demi menciptakan dampak positif baik bagi karyawan dan organisasi/ perusahaan.

Akan tetapi pada penelitian Plester et al. (2015), Yanti (2013), dan Lamm dan Meeks (2009) dalam Fluegge-Woolf (2014) ditemukan bahwa fun tidak dapat diterima secara langsung oleh semua orang, hal ini dikarenakan tidak semua orang memiliki persepsi yang sama mengenai fun dan bentuk kegiatan yang menciptakan fun itu sendiri. Fun tidak selalu dianggap sebagai hal yang menyenangkan dan memiliki dampak positif terhadap semua orang, persepsi berbeda terhadap fun itulah yang mempengaruhi keharmonisan dalam organisasi bahkan dapat memicu konflik.

Hasil penelitian yang tidak sejalan ini diduga karena dipengaruhi oleh persepsi mengenai fun at work yang dirasakan oleh karyawan di Atria Hotel Gading Serpong berbeda-beda dan karyawan cenderung tidak merasa fun di tempat kerja mereka. Berdasarkan profiling responden, dapat dilihat bahwa mayoritas karyawan Atria Hotel Gading Serpong adalah laki-laki, berusia produktif, dan memiliki masa kerja kurang dari 1 tahun, sehingga mayoritas karyawan belum terlalu dapat merasakan adanya aktifitas yang menyenangkan di tempat kerja, seperti melalui perayaan di kantor yang biasanya dilakukan hanya setiap 3 atau 6 bulan sekali. Sehingga dimensi celebrating at work tidak berpengaruh terhadap perilaku OCB karyawan. Selain itu, karyawan dengan masa kerja kurang dari 1 tahun juga diduga belum dapat menjalin keakraban yang erat dengan karyawan lain, sehingga tidak tercipta persahabatan di tempat kerja dan dimensi socializing with coworkers tidak berpengaruh terhadap perilaku OCB karyawan.

Melalui hasil angket terbuka yang dijawab oleh responden, karyawan memberikan masukan bagi HR Department untuk menambah aktivitas / perayaan yang bersifat refreshment. Hal ini juga diduga menjadi salah satu alasan lemahnya kesenangan di tempat kerja yang dirasakan oleh karyawan. Selain itu, karyawan juga merasa bahwa pemberian training / kegiatan lainnya seringkali tidak sesuai dengan schedule karyawan, dimana pelaksanaan training / 
kegiatan lainnya tersebut terkadang dilakukan pada jam pulang kerja atau jadwal libur karyawan. Hal ini diduga dapat memicu stres dan membuat karyawan tidak merasakan kesenangan di tempat kerja.

\section{Pengaruh Work Engagement terhadap OCB}

Work Engagement terbukti memiliki hubungan yang positif terhadap OCB, yaitu sebanyak $15.6 \%$. Hal ini sejalan dengan hasil penelitian yang dilakukan oleh Mathumbu dan Dodd (2013) yang menyatakan bahwa work engagement memiliki pengaruh yang signifikan dan berkorelasi positif terhadap $O C B$. Hal ini juga sejalan dengan penelitian Ziyad (2015) yang menunjukkan bahwa keterikatan kerja berpengaruh secara signifikan terhadap $O C B$. Oleh karena itu karyawan Atria Hotel Gading Serpong dapat dicirikan sebagai karyawan yang fokus dalam menyesuaikan suatu pekerjaan dan juga pada pekerjaan yang berikutnya, merasakan diri adalah bagian dari sebuah tim dan sesuatu yang lebih besar daripada diri mereka sendiri, merasa mampu dan tidak merasakan sebuah tekanan dalam membuat sebuah lompatan dalam pekerjaan, dan mampu bekerja dengan perubahan dan mendekati tantangan dengan tingkah laku yang dewasa, sesuai dengan teori karakteristik work engagement yang dikemukakan Federman (2009) dalam Mujiasih (2015).

\section{Pengaruh Job Satisfaction terhadap OCB}

Job Satisfaction terbukti memberikan pengaruh paling besar terhadap OCB dibandingkan dengan komponen pembentuk OCB, yaitu sebesar $34,6 \%$. Hal ini sejalan dengan penelitian Gyekye dan Haybatollahi (2015) yang menyatakan kepuasan kerja merupakan prediktor yang signifikan terhadap $\mathrm{OCB}$, yang dibuktikan dengan karyawan yang lebih muda akan memiliki perilaku OCB ketika merasa kepuasan kerja sudah terpenuhi. Hal ini juga sejalan dengan penelitian Robbins dan Judge (2015) yang menjelaskan bahwa job satisfaction merupakan prediktor utama dari OCB. Karyawan yang lebih puas akan cenderung merespon pengalaman positif mereka dengan berbicara positif mengenai organisasi, membantu rekan kerja, dan melebihi ekspektasi dalam menyelesaikan pekerjaannya.

Pengaruh job satisfaction terhadap OCB karyawan dapat dijelaskan oleh beberapa faktor. Kepuasan terhadap rekan kerja dapat meningkatkan dimensi OCBI yaitu courtesy dan altruism. Kepuasan pada rekan kerja ditunjukkan dengan komunikasi dan interaksi yang baik antar karyawan Atria Hotel Gading Serpong. Hal itu menciptakan suasana kondusif dan hubungan yang baik sehingga perilaku courtesy dan altruism meningkat. Perilaku courtesy ditunjukkan dengan sikap saling menghormati antar karyawan Atria Hotel Gading Serpong sehingga tidak terjadi konflik. Perilaku altruism ditunjukkan dengan empati dan sikap saling membantu karyawan Atria Hotel Gading Serpong dengan rekan kerja yang mengalami masalah.

Kepuasan pada compensation dapat meningkatkan perilaku OCB yaitu Civic Virtue. Karyawan Atria Hotel Gading Serpong yang puas dengan compensation akan merasa bahwa tugas dan imbalan yang diterima telah sesuai, sehingga perilaku Civic Virtue meningkat. Hal ini sesuai dengan hasil angket terbuka yang diajukan pada karyawan, dimana karyawan sudah merasa puas dengan pendapatan yang mereka terima setiap bulan, serta benefit yang diberikan oleh Atria Hotel Gading Serpong bagi karyawan seperti tunjangan kelahiran dan pernikahan.

\section{Simpulan}

Kesimpulan yang dapat diperoleh berdasarkan hasil dan analisa data dalam penelitian ini diuraikan sebagai berikut: Hasil analisis data menunjukkan bahwa fun at work tidak memberikan pengaruh positif terhadap $O C B$ karyawan di Atria Hotel Gading Serpong. Artinya, kesenangan yang dirasakan karyawan di tempat kerja tidak berpengaruh dalam meningkatkan perilaku $O C B$ yang dimiliki karyawan. Hasil analisis data menunjukkan bahwa work engagement memberikan pengaruh positif terhadap $O C B$ pada karyawan di Atria Hotel Gading Serpong. Artinya jika keterikatan kerja yang dimiliki karyawan meningkat, maka hal tersebut juga akan meningkatkan perilaku $O C B$ yang dimiliki karyawan. Hasil analisis data menunjukkan bahwa job satisfaction memberikan pengaruh 
positif terhadap $O C B$ pada karyawan di Atria Hotel Gading Serpong. Artinya jika kepuasan kerja yang dirasakan karyawan meningkat, maka hal tersebut juga akan meningkatkan perilaku $O C B$ yang dimiliki karyawan.

\section{Saran}

Berikut adalah saran yang dapat penulis berikan untuk penelitian serupa selanjutnya di masa mendatang: Memperhatikan perbedaan kelompok generasi pada responden. Suasana kerja yang nyaman, menyenangkan, tidak dapat diterima oleh semua lapisan, dimulai dengan angkatan baby boomers secara khusus, yang sangat menolak suasana fun, angkatan tersebut senang akan tantangan, tekanan dan kinerja (Zemke et al., 2000 dalam Tews, 2015). Persepsi boomers bahwa workplace fun merupakan tempat kerja yang counterproductive terhadap persaingan. Sedangkan, Generation Xers menempatkan fun dalam bentuk yang sempit yaitu berekreasi dan bersenang-senang di luar, bukan area kerja. Terakhir, angkatan Gen-Y (Millenials), memandang bahwa pekerjaan merupakan hal yang utama dalam membangun karir (Howe dan Strauss, 2000 dalam Tews, 2015) dan sangat penting menciptakan satu kondisi yang dapat memunculkan komitmen karyawan terhadap organisasi dalam jangka panjang. Penelitian selanjutnya disarankan untuk menggunakan model penelitian kualitatif agar dapat mengeksplorasi permasalahan dan hasil penelitian dengan pemahaman lebih mendalam. Penelitian selanjutnya diharapkan dapat menemukan variabel lain yang dapat memengaruhi atau memoderasi hubungan fun at work dengan $O C B$ karena banyak faktor yang belum dapat dijelaskan dalam model penelitian.

\section{Daftar Pustaka}

Arasli, H. \& Baradarani, S., (2010). Toward business excellence in hospitality industry in Iran: a case for 3, 4, 5 star hotels. The Second Canadian Quality congress-Toronto.

Chan, S. C. H., \& Mak, W. M., (2016), Have you experienced fun in the workplace? An empirical study of workplace fun, trust-in-management, and job satisfaction. Journal of Chinese Human Resources Management, 2016, v. 7, no. 1, p. 27-38.

Fluegge-Woolf, E. R., (2014). Play hard, work hard, Management Research Review, Vol. 37 Iss 8 pp. $682-705$.

Geldenhuys, M., Laba, K., \& Venter, C.M. (2014). Meaningful work, work engagement and organisational commitment, SA Journal of Industrial Psychology, 40 (1), 10 pages

Gyekye, S. A., \& Haybatollahi, M. (2015) Organizational citizenship behaviour: An empirical investigation of the impact of age and job satisfaction on Ghanaian industrial workers, International Journal of Organizational Analysis, Vol. 23 Issue: 2, pp.285-301

Hemaloshinee, V., \& Nomahaza, M. (2017). Organizational citizenship behavior in hospitality industry: Bridging challenges, benefits and contribution, International Business School, University Technology Malaysia, 2(3): 243-250

Hotelier Indonesia Magazine. (2018). Retrieved March 11, 2018, from http://www.hotelierindonesia.com/2018/03/indonesiahotel-performance-highlights.html

Irawan, D. B. (2016). 5 Hotel yang mengelilingi Summarecon Mal Serpong. Retrieved March 11, 2018, from http://tangerangnews.com/properti/rea d/17703/5-Hotel-yang-mengelilingiSummarecon-Mal-Serpong/1

Malhotra, N. K. (2012). Basic Marketing Research: Integration of Social Media, 4th edition. New Jersey: Pearson Education.

Mark, K.; Zaiton, H., (2015). The role of flow between burnout and organizational citizenship behavior (OCB) among hotel 
employees in Malaysia. Pro. Soc. Behav. Sci., 211: $199-206$.

Marketeers.com (2016). Hotel Tumbuh, Namun Sulit Mencari Pegawai. Ada Apa?. Retrieved March 11, 2018, from http://marketeers.com/hotel-tumbuhnamun-sulit-mencari-pegawai-ada-apa/

Mathumbu, D \& Dodd, N. (2013). Perceived organisational support, work engagement and organizational citizenship behavior of nurses at victoria hospital, Journal Psychology University of Fort Hare. 4 (2), 87 - 93

Mujiasih, E. (2015). Hubungan antara persepsi dukungan organisasi dengan keterikatan karyawan, Jurnal Psikologi Undip Vol.14 No.1 April 2015, 40-51

Nurcaya, I. (2017). Industri Perhotelan: Pasar Indonesia yang Kian Menggoda. Retrieved March 10, 2018 from http://banten.bisnis.com/read/2017071 0/449/670029/industri-perhotelanpasar-indonesia-yang-kian-menggoda

Plester, B., Cooper-Thomas, H., \& Winquist J., (2015). The fun paradox, Employee Relations, Vol. 37 Iss 3 pp. 380 - 398

Robbins, S.P dan Timothy A. Judge. 2015. Perilaku Organisasi. Jakarta : Salemba Empat.

Ruizalba, J. L., Guillermo, B.G., Miguel, A. R.M., \& Blanca, M. J. (2014). Internal market orientation: an empirical research in hotel sector, International Journal Hospitality Management, 38: 11-19

Siswono, D. (2016). Pengaruh Employee Engagement terhadap Kinerja Karyawan di Rodex Travel Surabaya, AGORA Vol. 4, No. 2.

Sugiyono. 2010. Metode penelitian Kuantitatif Kualitatif dan RND. Bandung: Alfabeta.

Tews, M., Michel, J., Xu, S., \& Drost, A., (2015), Workplace fun matters... but what else?, Employee Relations: The International Journal, Vol. 37 Iss 2 pp.

Yanti. (2013). Pengaruh Workplace Fun Terhadap Kinerja Karyawan berdasarkan Generational Differences (Studi pada PT BXY). Jurnal. Jakarta: Fisip UI.

Yulianti, P., \& Puteri, E. A. H. (2016). Peran Mediasi Affective Commitment pada Hubungan Procedural Justice, Perceived Organizational Support dengan Employee Engagement, Jurnal IImu Ekonomi \& Sosial, Vol.VII, No. 1; 14-27

Ziyad. (2015). Pengaruh Kepuasan Kerja, Keterikatan Kerja dan Kepribadian terhadap OCB (Studi kasus pada karyawan PT Stainless Steel Primavalve Maju Bersama), Universitas Mercu Buana, Jakarta 